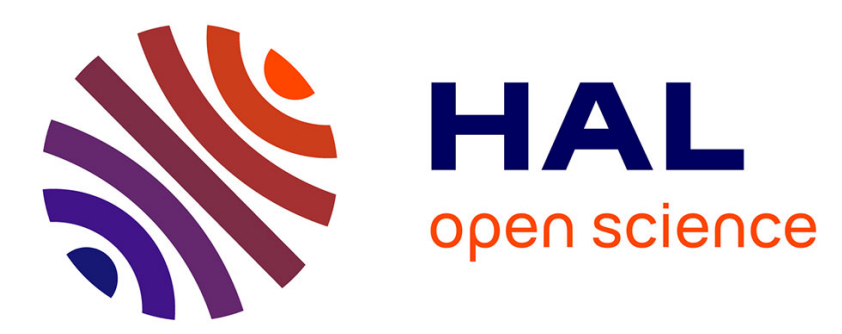

\title{
Differences between queen- and worker-laid male eggs of the honey bee (Apis mellifera)
}

Jakob Wegener, Matthias W. Lorenz, Kaspar Bienefeld

\section{To cite this version:}

Jakob Wegener, Matthias W. Lorenz, Kaspar Bienefeld. Differences between queen- and worker-laid male eggs of the honey bee (Apis mellifera). Apidologie, 2010, 41 (1), 10.1051/apido/2009061 . hal00892054

\section{HAL Id: hal-00892054 \\ https://hal.science/hal-00892054}

Submitted on 1 Jan 2010

HAL is a multi-disciplinary open access archive for the deposit and dissemination of scientific research documents, whether they are published or not. The documents may come from teaching and research institutions in France or abroad, or from public or private research centers.
L'archive ouverte pluridisciplinaire HAL, est destinée au dépôt et à la diffusion de documents scientifiques de niveau recherche, publiés ou non, émanant des établissements d'enseignement et de recherche français ou étrangers, des laboratoires publics ou privés. 


\title{
Differences between queen- and worker-laid male eggs of the honey bee (Apis mellifera)*
}

\author{
Jakob WEGENER $^{1}$, Matthias W. LORENZ ${ }^{2}$, Kaspar BIENEFELD ${ }^{1}$ \\ ${ }^{1}$ Institute for Bee Research, F.-Engels-Strasse 32, 16540 Hohen Neuendorf, Germany \\ ${ }^{2}$ Department of Animal Ecology I, University of Bayreuth, 95440 Bayreuth, Germany
}

Received 12 March 2009 - Revised 13 July 2009 - Accepted 14 July 2009

\begin{abstract}
In this study, we investigated whether differences in the reproductive biology of honey bee (Apis mellifera) queens and laying workers are reflected in their eggs. We first tested the capacity of queen- and worker-laid male eggs to withstand dry conditions, by incubating samples at 30.0,74.9, and $98.7 \%$ relative humidity. We found that worker-laid eggs were more sensitive to desiccation. Secondly, we measured the weight and quantities of vitellin, total protein, lipid, glycogen, and free carbohydrate in queen- and workerlaid eggs. Although worker-laid eggs were found to be heavier than queen-laid eggs in two of the four replicates, no systematic differences were found regarding nutrient content. Finally, we compared the duration of embryo development in the two egg types. Worker-laid eggs developed more slowly than queen-laid eggs in two out of three replicates, suggesting that they may only be partly mature at the moment they are laid. Possible causes and consequences of the observed differences are discussed.
\end{abstract}

\section{Apis mellifera / egg / hatching rate / nutrient / laying worker}

\section{INTRODUCTION}

Although the honey bee (Apis mellifera) is characterized by reproductive division of labour, workers of this species have kept the ability to reproduce. Since they cannot mate, they produce offspring parthenogenetically (Dzierzon, 1845, cited in Buttel-Reepen, 1915). In the majority of subspecies, all or almost all worker-laid eggs are haploid (produced by arrhenotokous parthenogenesis) and develop into males. An exception is the Cape honey bee (A. m. capensis), whose workers are able to lay diploid, female eggs by thelytokous parthenogenesis (Onions, 1912, cited in Anderson, 1963).

Visscher (1996) estimates that in queenright colonies of mixed European origin, only approximately $7 \%$ of all male eggs originate from laying workers. However, if the queen is lost and cannot be replaced, mass egg-laying

Corresponding author: K. Bienefeld, kaspar.bienefeld@rz.hu-berlin.de

* Manuscript editor: Stefan Fuchs by workers often occurs and several thousand worker-derived drones are produced before colonies break down due to the lack of young workers (Page and Erickson, 1988; Hemmling, 1991).

The anatomy of the reproductive organs and the reproductive physiology of queen and worker honey bees present striking differences. In European subspecies, the ovaries of queens contain approximately 130 to 200 ovarioles (Rhein, 1933; Snodgrass, 1956; Dade, 1962), compared to only 1 to 20 in workers (Zander, 1916, 1951; Rhein, 1933; Wegener et al., 2009), although the morphology and ultrastructure of the individual ovarioles of the two castes seems to be almost indistinguishable (Reginato and Cruz-Landim, 2003; Tanaka and Hartfelder, 2004). During peak egg-laying periods, a queen may produce 1500 or more eggs/day (Buttel-Reepen, 1915; Snodgrass, 1956), compared to 5 to 38 for individual laying workers (Perepelova, 1928, cited in Ribbands, 1953; Visscher, 1996). The vagina is much shorter in workers, 
and the spermatheca (which in the queen serves to store semen) is rudimentary (Zander, 1916; Snodgrass, 1956). Workers also lack the valve fold (Zander, 1916, 1951), a structure that in queens is thought to press ovulated eggs against the opening of the spermathecal duct.

Tanaka and Hartfelder (2004) performed a detailed morphological study on the early stages of oogenesis, and they found almost no differences between the two castes. Comparative data on the mature eggs are scant and sometimes contradictory. Hatching rates of queen-laid (QL) and worker-laid (WL) eggs have been compared in four studies. Two of these came to the conclusion that they are lower in WL eggs (Velthuis et al., 2002; Pirk et al., 2004), one found no difference (Ratnieks and Visscher, 1989), and one found slightly lower hatching rates in QL eggs (Beekman and Oldroyd, 2005).

The objective of the present study was to determine if and how anatomical and physiological differences between queens and workers are reflected in the properties of their unfertilised, male eggs. Velthuis et al. (2002) observed that compared to QL eggs, WL eggs frequently desiccated during incubation. In a first experiment, we therefore compared the sensitivity of the two types of eggs to desiccation. Velthuis et al. (2002) also observed that about half of the WL eggs they incubated hatched "with a delay", although they did not give any details about its length. In a second experiment, we therefore compared the duration of embryonic development of QL and WL eggs to assess whether WL eggs may be partly immature at the moment they are laid.

Gontarski (1938) and Woyke (1994) found that in $A$. m. mellifera, ripe QL eggs were longer but narrower than WL eggs, and Gontarski reports that the volume of WL eggs is, on average, $45 \%$ higher than that of QL eggs. Gençer and Woyke (2006) showed that in $A$. $m$. caucasica, QL eggs were on average both smaller and lighter than WL ones. To explain their findings, the latter authors hypothesised that as workers lay far fewer eggs than queens, they are able to invest more into each of them. Here we quantified several important classes of nutrients in both QL and WL eggs, with the aim of verifying this assumption.

WL eggs are usually quickly and selectively removed from queenright colonies by other workers. This fact was first hypothesized by Gontarski (1938) and has first been shown experimentally by Ratnieks and Visscher (1989). It has recently been the subject of a lively debate, centering around the cues by which the workers that remove the eggs can distinguish between worker- and queen-laid ones (e.g., Ratnieks, 1992, 1995; Katzav-Gozansky et al., 1997, 2001, 2003; Pirk et al., 2004; Beekman and Oldroyd, 2005), and the ultimate reason(s) for the evolution of worker egg removal (e.g., Woyciechowski and Lomnicki, 1987; Ratnieks and Visscher, 1989; Pirk et al., 2004; Nonacs, 2006). It was not the main objective of our study to conclusively solve these issues, but physical differences between QL and WL eggs may potentially be of importance in this context.

\section{MATERIALS AND METHODS}

All colonies used were of the subspecies $A$. $m$. carnica and were housed in the apiary of the Institute for Bee Research, Hohen Neuendorf (Germany). The significance level for all statistical tests was set at $\alpha=0.05$. SPSS 10.0 (SPSS Inc., Chicago, USA) was used for data analysis.

\subsection{Influence of air humidity and forceps transfer on queen- and worker-laid eggs}

The principle of this experiment is depicted in Figure 1. For each of three replicates, one colony was split into equal halves of approximately 15000 workers. One received the original queen, while the other remained queenless. Replacement queen cells were removed from the queenless part after 7-8 days. After four to five weeks, when mass egg-laying by workers had started in the queenless half, freshly-built drone combs were inserted into both halves. In the queenright part, the queen was confined to the drone comb by means of a cage made of queen excluder material. After $24 \mathrm{~h}$, the queen was freed and the egg-containing combs removed from both hives. Three pieces were cut out of each comb, and the position of thirty eggs on 


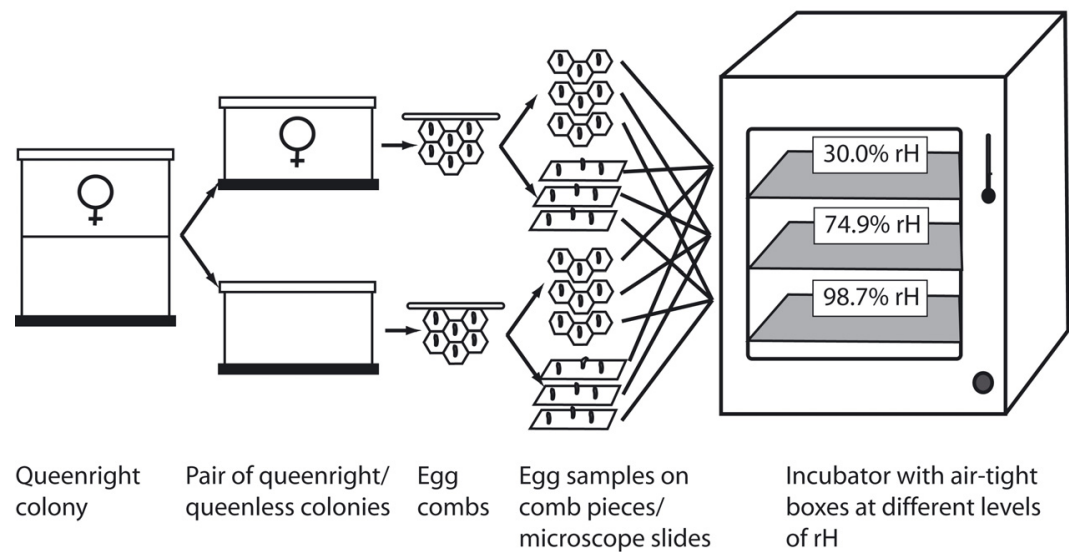

Figure 1. Experimental design to test the influence of air humidity on the hatching success of queen- and worker-laid eggs.

each piece was noted on transparent plastic films. From the remaining parts of both combs, groups of thirty eggs were transferred with a pair of speciallydesigned forceps (Taber, 1961) onto each of three beeswax-coated microscope slides. Egg samples on comb pieces and on microscope slides were then transferred to each of three Petri dishes. The Petri dishes were placed without covers inside tightlyclosing plastic boxes, where they were installed over saturated solutions of $\mathrm{CaCl}_{2}$ or $\mathrm{NaCl}$ with large amounts of residuum, or over wet filter paper. The boxes were placed into an incubator at $34.4 \pm 0.3{ }^{\circ} \mathrm{C}$. Relative air humidity inside the boxes after $>1 \mathrm{~h}$ of incubation was $30.0 \pm 4.1 \%\left(\mathrm{CaCl}_{2}\right)$, $74.9 \pm 3.0 \%(\mathrm{NaCl}$ ), and $98.7 \pm 0.3 \%$ (wet filter paper).

Unrelated colonies were used for the three replicates. In total, 36 egg samples (1080 eggs) were incubated. The proportions of hatching eggs from these 36 samples were submitted to a three-factorial analysis of variance (ANOVA) after verification that the data met the statistical preconditions. The three factors were egg type (QL of WL), forceps transfer (yes or no), and air humidity (30.0, 74.9 or $98.7 \%$ ). A saturated model was used. Pairwise comparisons of queen- and worker-laid eggs at all three levels of relative humidity were made for the samples of untransferred eggs, using Student's t-tests.

\subsection{Duration of embryonic development of queen- and worker-laid eggs}

Three colonies of approximately 30000 workers each and with unrelated, mated queens were used. Three hundred grams of bees (ca. 3000 individuals) were taken from the brood nest of each colony and placed inside small hive boxes for mating nuclei (F. Wienold, Germany), also containing one comb of honey, one empty comb, one comb of young worker brood and one comb of pollen. They were kept in a dark and cool room overnight and installed in the apiary the next morning. The combs containing young worker larvae were removed after 2-3 days, so that the colonies lost any chance of rearing replacement queens. Mass worker egg-laying started after 9-14 days. After this time, eggs from the queenless and queenright colonies were obtained as in experiment 1 , except that egglaying was stopped after $12 \mathrm{~h}$ instead of $24 \mathrm{~h}$. Samples of 153-242 eggs were transferred from each comb onto wax-coated plastic supports using forceps. They were incubated at $34.5 \pm 0.3{ }^{\circ} \mathrm{C}$ and high humidity (approximately $98 \% \mathrm{RH}$ ). The number of larvae that had hatched was determined every $12 \mathrm{~h}$. The progression of hatching of the egg types was compared by life table analysis followed by Gehan's generalized Wilcoxon test.

\subsection{Weight and nutrient content of queen- and worker-laid eggs}

Samples of eggs from four pairs of queenright and queenless colonies were obtained as in experiment 2 (but from other colonies). Egg-laying in the queenless parts started after 10 to 14 days. From each pair of colonies, thirty eggs of each type were placed individually into $200 \mu \mathrm{L}$ of buffer solution (0.05 mol/L TRIS, $0.16 \mathrm{~mol} / \mathrm{L} \mathrm{NaCl}, \mathrm{pH} 8.5)$ and 
immediately frozen at $-20{ }^{\circ} \mathrm{C}$. They were transported on dry ice to the University of Bayreuth, where they were homogenized using a mortar-pestle (Xenox MHX E; Proxxon, Niersbach, Germany) and an aliquot $(2 \mu \mathrm{L})$ from each sample was taken for the estimation of vitellin by an enzyme-linked immunosorbant assay (Wegener et al., 2009). Then, $100 \mu \mathrm{L}$ of a saturated $\mathrm{Na}_{2} \mathrm{SO}_{4}$-solution was added to the remaining homogenate and the whole mixture evaporated to dryness in a vacuum centrifuge (SpeedVac alpha RVC; Christ, Osterode, Germany). The subsequent separation into substance classes (lipid, protein, free carbohydrates, glycogen) and the colorimetric estimation of the components was carried out as described in Lorenz (2003) with the modifications described in Lorenz (2007).

Additionally, groups of 30 eggs from each colony were weighed to the nearest $\mu \mathrm{g}$ on a microbalance (Model M5P, Sartorius, Hanau, Germany). Hatching success of the queen- and worker-laid eggs was measured by incubating samples of 38 to 82 eggs on pieces of their original combs at $34.5 \pm 0.3{ }^{\circ} \mathrm{C}, 49.1 \pm 5.6 \% \mathrm{RH}$.

Data on egg weight as well as on contents of all the nutrients measured showed heterogeneity of variances, so that they could not be analysed by ANOVA. Therefore, the effect of egg type (QL or WL) on nutrient contents was tested separately for each nutrient class and pair of colonies. Depending on the outcome of Levene's test for homogeneity of variances, either the exact or the asymptotic $t$-test was used for these comparisons. To determine whether the colony of origin had an influence on egg weight or composition, Kruskal-Wallis tests were applied to data of QL and WL eggs.

\subsection{Limitations to the validity of the methodology}

1. The duration of queenlessness or of worker egglaying may potentially influence the properties of WL eggs (Beekman and Oldroyd, 2005; Wegener and Bienefeld, 2009). All WL eggs used in our experiments were sampled shortly after the onset of mass worker laying, and so our results are representative only of the eggs laid during this phase.

2. In experiments 2 and 3 , the size of queenless and queenright colonies was not equal. While, to our knowledge, there is no evidence to suggest that colony size affects the properties of honey bee eggs, we cannot rule out this possibility.

\section{RESULTS}

\subsection{Influence of air humidity and forceps transfer on queen- and worker-laid eggs (Fig. 2)}

Relative humidity had a significant influence on the hatching success of all eggs (ANOVA F-test for factor "humidity"; $\mathrm{df}=2$; $F=33.96 ; P<0.001)$. Eggs transferred with forceps showed lower hatching success than untransferred eggs (factor "forceps"; $\mathrm{df}=1$, $F=52.05, P<0.001)$. Egg type (QL or WL) also had a significant effect on the survival of the eggs to the larval stage ( $\mathrm{df}=1 ; F=20.48$; $P<0.001$ ). The influence of relative humidity was greater in the case of worker-laid than of queen-laid eggs (interaction between factors "humidity" and "egg type"; df $=2 ; F=4.49$; $P=0.02$ ). For against, the interaction between factors "egg type" and "forceps transfer" was not significant (df $=1 ; F=3.71$; $P=0.07$ ). Untransferred QL eggs had higher hatching rates than untransferred WL eggs at $30.0 \%$ relative humidity $(\mathrm{df}=4 ; t=4.5 ; P=$ $0.011)$. Hatching rates did not differ at 74.9 and $98.7 \% \mathrm{RH}(t=0.9 ; P=0.433$ and $t=1.7$; $P=0.64$, respectively).

\subsection{Duration of embryonic development of queen- and worker-laid eggs (Fig. 3)}

Worker-laid eggs hatched later than eggs laid by queens in two of the three trials ( $\mathrm{df}=1$; Wilcoxon Gehan statistic 33.2 and $39.4 ; P<0.001$ in both cases), but not in the third ( $\mathrm{df}=1$; Wilcoxon Gehan statistic $0.32 ; P=0.576)$.

\subsection{Weight and nutrient content of queen- and worker-laid eggs (Fig. 4)}

No effect of egg type (QL or WL) existed on the amounts of free carbohydrates and total protein in eggs of any of the four pairs of queenless and queenright colonies $(P>0.05)$. Glycogen content was higher in the WL sample of one pair of colonies (exact $t$-test; $\mathrm{n}=$ 

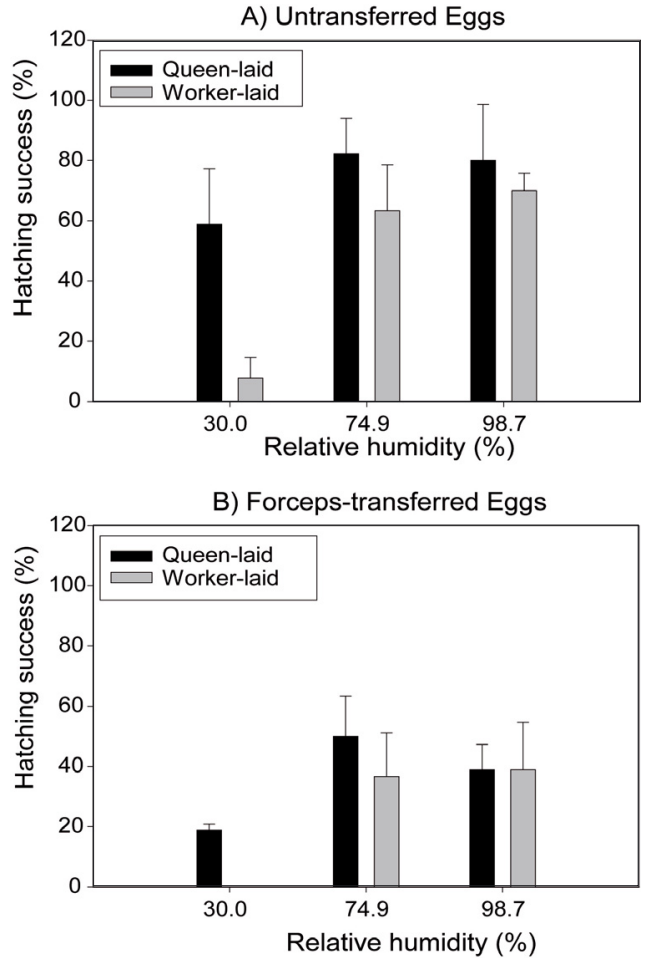

Figure 2. Hatching success of queen- and workerlaid eggs at different levels of relative humidity. Thirty eggs were incubated per colony. Means \pm standard deviations are given $(n=3$ pairs of colonies). Effects of egg type (queen- or workerlaid), relative humidity and forceps transfer were all significant (ANOVA, $P<0.001$ in all three cases). The interaction between egg type and relative humidity was also significant $(P=0.02)$, while other interactions were not $(P>0.07)$.

$59 ; t=-2.95 ; P=0.005)$, but in the QL sample of one other pair (exact t-test; $\mathrm{n}=59$; $t=3.94 ; P<0.001)$. Lipid contents were higher in queen-laid eggs in two cases (asymptotic t-tests; $\mathrm{n}=58$ and $59 ; t=4.85$ and 5.69; $P<0.001$ in both cases), but did not differ in the others $(P>0.18)$. Queen-laid eggs contained more vitellin in one pair of colonies (exact t-test; $\mathrm{n}=58 ; t=9.85 ; P<0.001)$, while no difference existed in the others $(P>0.09)$. In two replicates, the weight of worker-laid eggs was significantly higher (asymptotic ttest; $\mathrm{n}=60$ and $50 ; t=-11.86$ and $-4.80 ; P<$
0.001 in both cases). Weight differences were not significant in the other two $(P>0.15)$.

The effect of the colony of origin of the eggs on nutrient contents was not significant in the case of glycogen in WL samples (Kruskal-Wallis-test; $\mathrm{n}=118 ; \chi^{2}=0.63$; $P=0.88$ ). For all other combinations of nutrients and egg types, colony effects were highly significant (separate Kruskal-Wallis-tests for each combination of nutrient class and egg type; $\mathrm{n}=114-118 ; \chi^{2}=17.32$ to 55.92 ; $P \leq 0.001$ in all cases).

On the pieces of egg comb incubated at $50 \% \mathrm{RH}$, hatching success of queen-laid eggs was greater in three out of the four replicates $\left(\mathrm{n}=93-102 ; \chi^{2}=6.6-27.2 ; P=\right.$ 0.001-0.012), but did not differ between the egg types in the last $\left(\mathrm{n}=137 ; \chi^{2}=0.2\right.$; $P=0.709)$.

\section{DISCUSSION}

\subsection{Sensitivity of worker-laid eggs towards desiccation and mechanical stress}

Our results show that the answer to the question of whether the hatching rates of $\mathrm{QL}$ and WL eggs differ may depend on air humidity. Two out of four earlier studies addressing this question contain at least indirect information about air humidity during incubation.

Ratnieks and Visscher (1989) incubated eggs inside Petri dishes containing watersaturated pieces of cotton, so air humidity was probably close to $100 \%$. They found similar hatching rates for both egg types. This result is consistent with our own observations at $98.7 \% \mathrm{RH}$. Hatching rates of both egg types were higher in our study, which may be due to the fact that Ratnieks and Visscher used forceps-transferred eggs. Velthuis et al. (2002) held the eggs at 50\% RH in an incubator. Under these conditions, hatching success of WL eggs was lower than of QL ones. In the control treatment of our experiment on nutrient content, higher hatching rates for QL eggs were found in three pairs of colonies out of four $(\mathrm{RH}=49.1 \%)$. Therefore, it seems likely that some of the differences between the 


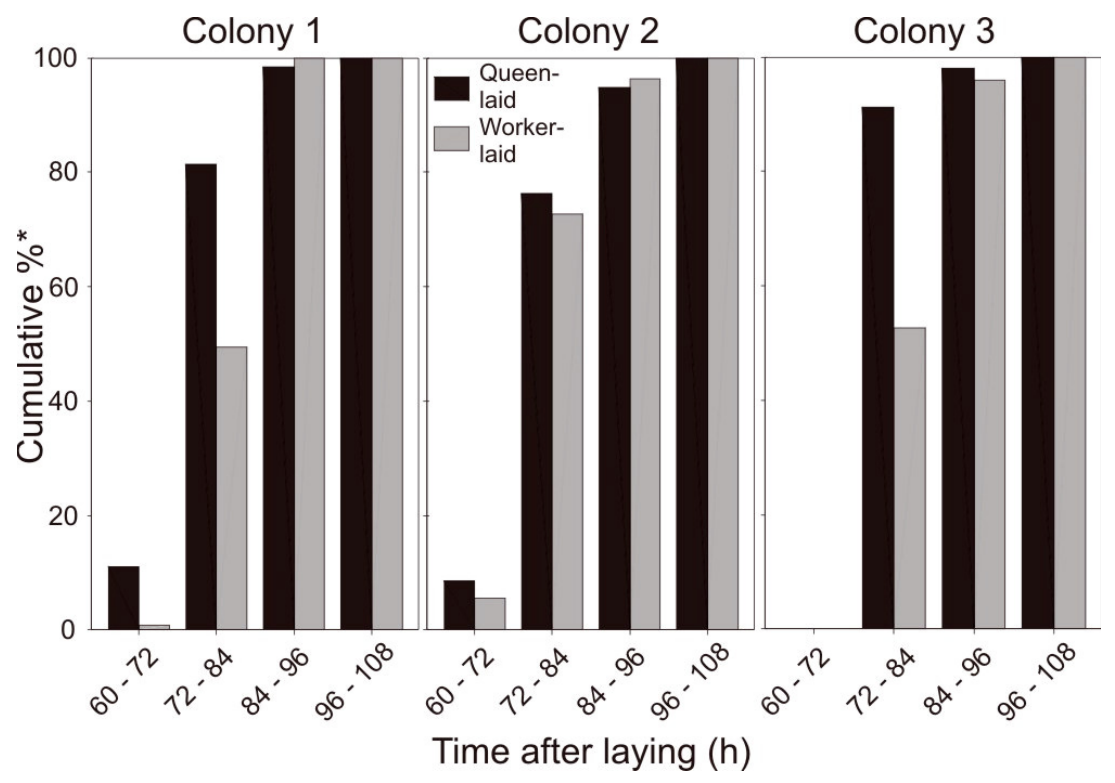

Figure 3. Duration of development of queen- and worker-laid eggs. $* 100 \%=$ total number of eggs that hatched successfully. $N=160,114$ and 204 in the three trials. The time course of hatching differed between queen- and worker-laid eggs in trials 1 and 3 (Gehan's generalized Wilcoxon test, $P<0.001$ in both cases), but not in trial $2(P=0.576)$.

findings of earlier studies concerning hatching rates of QL and WL eggs can be explained by different levels of air humidity during incubation.

An important question is whether hatching rates differ at the level of air humidity the eggs would experience under natural conditions. In the space between two combs at the center of the brood nest, air humidity can vary between 30 and over $70 \%$, with values around $40 \%$ being most frequently observed (Wohlgemuth, 1957; Büdel, 1948, 1960). Our data (experiment 1 and hatching controls of experiment 2) as well as those of Velthuis et al. (2002) and Ratnieks and Visscher (1989) indicate that the hatching rates of WL and QL eggs may differ at up to at least $50 \% \mathrm{RH}$, but not at or above $75 \% \mathrm{RH}$. In order to approximate natural conditions during egg incubation, Pirk et al. (2004) inserted egg combs into beetight wire-mesh pockets that they placed inside the brood nest of strong colonies. They measured hatching rates of only $22.8 \%$ in the WL samples, against $81.0 \%$ in the QL ones. However, it is not quite clear whether humidity between two combs at the centre of the brood nest really equals that of the air directly surrounding male eggs under natural conditions. Worker bees sometimes deposit small drops of water on the walls of cells containing eggs or larvae (Lindauer, 1954). Also, drone cells are not usually situated at the centre of the brood nest, but at its periphery (Buttel-Reepen, 1915; Winston, 1987, and literature cited therein), where relative humidity is generally slightly higher (Wohlgemuth, 1957; Büdel, 1960). Mackasmiel and Fell (2000) incubated WL eggs using a methodology similar to that of Pirk et al. (2004), and they found higher hatching rates $(60 \%)$. Therefore, it may be too early to conclude with certainty on whether or not hatching rates of QL and WL eggs differ under hive conditions.

\subsection{Maturity of worker-laid eggs}

Studies on the oocytes of different phyla have shown that embryonic development may be prolonged if activation occurs prematurely (Echinodermata: Schuetz, 1975; 

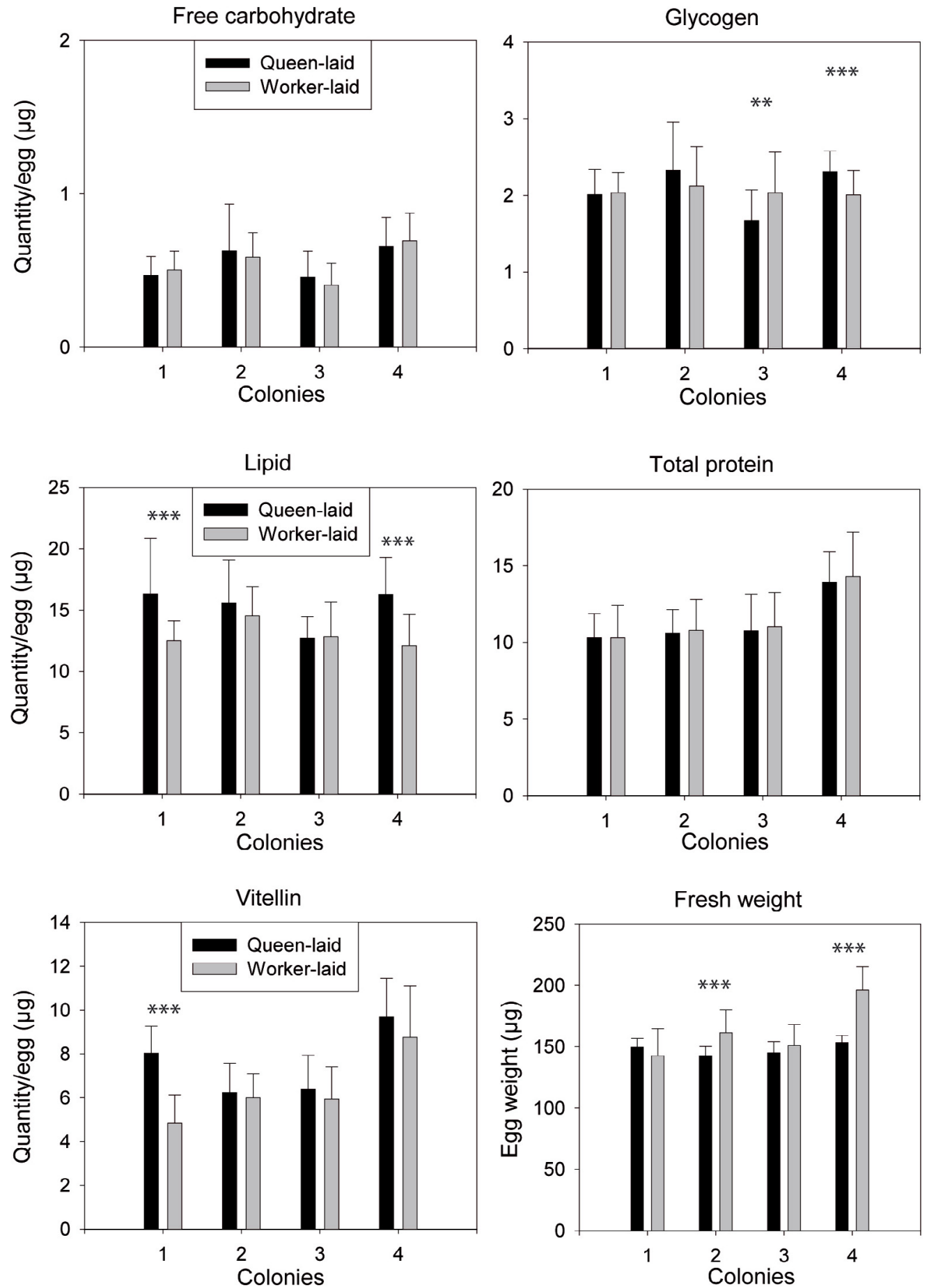

Figure 4. Weight of and quantities of nutrients contained in queen- and worker-laid eggs. Each bar represents the mean of 28-30 eggs \pm standard deviation. ** Means significantly different $(P<0.01)$. *** Means significantly different $(P<0.001)$. 
Mammalia: Leoni et al., 2006; Rizos et al., 2008). In the honey bee, Reinhardt (1960) has shown that oocyte maturation is more advanced in female than in male QL eggs at the time of egg-laying, and that embryo development takes longer in the former. The latter fact was also observed by Harbo and Bolten (1981). For A. cerana, Kapil (1962) has shown that because of anatomical differences, laying workers may have less control over ovulation than queens, which may lead to eggs being laid at an earlier stage.

In two out of three replicates of our experiment on the duration of embryonic development, worker-laid eggs were indeed found to hatch significantly later than QL eggs. This confirms the circumstantial observations of Velthuis et al. (2002), and supports the hypothesis of WL eggs being less mature at the moment of oviposition. Our finding that WL eggs are more sensitive to desiccation than QL eggs may also point in this direction, since the protection of insect eggs from dehydration depends on the properties of the shell, whose secretion by follicle cells forms one of the last steps of oogenesis (Trougakos and Margaritis, 2002).

An alternative explanation for the longer duration of development of WL eggs may lie in the fact that they also often bigger and/or heavier than QL eggs (see discussion below). Egg size and development time are positively correlated in many groups of organisms, especially in aquatic insects (inter-specific comparisons; Gillooly and Dodson, 2000; Gillooly et al., 2002).

\subsection{Weight and nutrient content of queen- and worker-laid eggs}

To our knowledge, this study is the first to present quantitative data on nutrients contained in honey bee eggs. The main storage protein is vitellin, and energy reserves are present mainly in the form of lipids. Regarding some classes of nutrients (especially free carbohydrates and total protein), colony effects seemed to be greater than the effect of the caste of the egg-laying bees. This suggests the existence of strong genetic and/or environmental influences on egg composition.

During her lifetime (typically 2 to 5 years), a queen may produce several hundreds of thousands of eggs (Snodgrass, 1956). This level of fertility is possible because she is constantly supplied with highly nutritious glandular secretions ("royal jelly") by attendant workers, and because her fat body and reproductive organs are proportioned for high rates of egg production (Engels, 1972; Winston, 1987). To our knowledge, no published data on total egg production by laying workers are available, but it can be expected to be far lower. Although laying workers are often fed jelly as well (Schäfer et al., 2006), their fat body and ovary are always much smaller than those of queens. Maximum daily egg numbers are about 100 times higher in queens than in laying workers (Perepelova, 1928, cited in Ribbands, 1953; Snodgrass, 1956). Gençer and Woyke (2006) argued that as workers lay smaller numbers of eggs, they may be able to invest more into each of them. However, although WL eggs were heavier than QL eggs in two replicates out of four, WL eggs rarely contained greater amounts of nutrients than QL eggs. This suggest that other reasons than differences in maternal investment are responsible for bigger size or weight sometimes measured in WL eggs.

In general, egg weights appeared to be more variable in the WL samples than in the QL ones. This is not surprising, given that many individuals contributed to the WL samples, but each QL sample originated from a single female. Interestingly, however, data on egg nutrients showed no such systematic difference of variances.

\subsection{Implications of the rearing of WL eggs for colony productivity}

Two reasons have been offered for the evolution of selective removal of WL eggs by other workers, which are not mutually exclusive. The first is that workers are on average more closely related to male eggs laid by the queen (their mother) then by other workers (most of which are their half sisters) (e.g. 
Woyciechowski and Lomnicki, 1987; Ratnieks and Visscher, 1989). The second is that rearing eggs from workers instead of male QL eggs may potentially represent a cost to colony productivity, thereby reducing the inclusive fitness of most colony members (Pirk et al., 2003, 2004; Nonacs, 2006). If it could be shown that mortality in WL eggs is higher than in QL eggs under natural conditions, then this would lend support to the second hypothesis. However, for the reasons discussed above, we are unable to conclude on this point with certainty. Hypothesis two would also be strengthened if WL eggs contained significantly fewer nutrients than QL eggs, raising the possibility of a reduced fitness of worker-derived larvae and adults. Our results show that eggs laid by workers occasionally contain lower amounts of certain classes of nutrients than eggs produced by the workers' mother, but these differences are not systematically found in all colonies, and inter-colony variation as well as variation within the samples of individual colonies is high. The differences do not seem to compromise the viability of WL eggs, since under conditions of high humidity, hatching success of WL and QL eggs was found to be similar.

\subsection{Dehydration - a possible cue for egg removal?}

To date, most studies trying to identify the cues by which workers distinguish between QL and WL eggs have concentrated on chemicals present (or not) on the egg surface (Ratnieks, 1992, 1995; Martin et al., 2002, 2004, 2005; Katzav-Gozansky et al., 1997, 2001, 2002). Alternatively, it has bees suggested that more WL eggs were removed by other worker bees because a greater proportion of them were dead (Velthuis et al., 2002; Pirk et al., 2004). This view was refuted by Beekman and Oldroyd (2005), who showed that eggs killed by $\mathrm{CO}_{2}$-exposure were not removed faster than untreated (mostly viable) eggs.

In the present study, we show that WL eggs are more sensitive to dehydration than QL eggs. This leads to the question of whether this difference can be perceived by workers and may play a role in triggering removal of WL eggs. Even if dehydration of WL eggs should not lead to an increase of mortality under hive conditions, it could still be detectable by worker bees. We would like to emphasize, however, that our data were obtained with WL eggs produced under queenless conditions. As oogenesis in queenright and queenless laying workers may be slightly different (Ratnieks, 1995), our results are not necessarily representative of the type of eggs most relevant to the discussion about egg removal. Nevertheless, the influence of dehydration on egg removal may be an interesting topic for future research.

\section{ACKNOWLEDGEMENTS}

The work of J.W. was made possible by a grant from the Schaumann-Stiftung. The analysis of egg nutrients was funded by a grant from the Deutsche Forschungsgemeinschaft to M.W.L. (Lo 697/4-4). We thank Ursula Wilczek for expert technical assistance.

Les œufs donnant des mâles sont-ils différents selon qu'ils sont pondus par une reine ou une ouvrière pondeuse chez l'Ábeille (Apis mellifera)?

Apis mellifera / taux d'éclosion / ouvrière pondeuse / nutriments

Zusammenfassung - Unterschiede zwischen Drohneneiern gelegt von Königinnen und Arbeiterinnen der Honigbiene (Apis mellifera). Königinnen und legende Arbeiterinnen der Honigbiene (Apis mellifera) unterscheiden sich in der Anatomie ihrer Geschlechtsorgane sowie in der Anzahl an Eiern, die sie produzieren können. Hier haben wir untersucht, ob sich die von beiden produzierten männlichen Eier ebenfalls unterscheiden. Zunächst verglichen wir die Schlupfraten von Königinnen-gelegten $(\mathrm{Kg})$ und Arbeiterinnengelegten (Ag) Eiern aus drei Paaren von weiselrichtigen und weisellos Völkern bei unterschiedlichen Niveaus der relativen Luftfeuchte (Abb. 1, 2). Beide Eitypen zeigten sich empfindlich gegenüber Trockenheit, bei den Ag Eiern war dieser Effekt ausgeprägter als bei den $\mathrm{Kg}$ Eiern. Bei hoher Luftfeuchte unterschieden sich die Schlupfquoten der zwei Eitypen nicht voneinander.

In einem zweiten Experiment verglichen wir die Entwicklungsdauer von $\mathrm{Ag}$ und $\mathrm{Kg}$ Eiern. In zwei 
von drei Wiederholungen setzte der Eischlupf im Mittel bei den $\mathrm{Kg}$ Eiern früher ein (Abb. 3). Möglicherweise sind Ag Eier im Augenblick der Ablage in einem weniger fortgeschrittenen Entwicklungsstadium.

Es ist bekannt, dass Ag Eier häufig größer und/oder schwerer sind als $\mathrm{Kg}$ Eier. Dies wurde damit erklärt, dass Arbeiterinnen eine geringere Anzahl an Eiern legen und daher mehr in jedes davon investieren könnten. Um das zu prüfen, haben wir die Mengen an Vitellin, Gesamtprotein, Glykogen, freiem Kohlenhydrat und Lipiden in Eiern aus vier Paaren von weiselrichtigen/weisellosen Völkern gemessen (Abb. 4). Ag Eier enthielten selten mehr Nährstoffe als Kg Eier, so dass die Hypothese widerlegt werden konnte.

Aus weiselrichtigen Völkern werden Ag Eier bekanntermaßen selektiv entfernt. Die höhere Empfindlichkeit gegenüber Dehydrierung könnte den beteiligten Arbeiterinnen dabei potentiell als Erkennungsmerkmal für $\mathrm{Ag}$ Eier dienen.

\section{Apis mellifera / Ei / Schlupfrate / Nährstoff / legende Arbeiterin}

\section{REFERENCES}

Anderson R.H. (1963) The laying worker in the Cape honey bee, Apis mellifera capensis, J. Apicult. Res. 2, 85-92.

Beekman M., Oldroyd B.P. (2005) Honeybee workers use cues other than egg viability for policing, Biol. Lett. 1, 129-132.

Büdel A. (1948) Der Wasserdampfhaushalt im Bienenstock, Z. Vergl. Physiol. 31, 249-273.

Büdel A. (1960) Bienenphysik, in: Büdel A., Herold E. (Eds.), Biene und Bienenzucht, Ehrenwirth, Munich, pp. 115-180.

Buttel-Reepen H. v. (1915) Leben und Wesen der Biene, F. Vieweg und Sohn, Braunschweig.

Dade H.A. (1962) Anatomy and dissection of the honeybee, International Bee Research Association, London.

Engels W. (1972) Quantitative Untersuchungen zum Dotterprotein-Haushalt der Honigbiene (Apis mellifica), Wilhelm Roux' Archiv 171, 55-86.

Gençer H.V., Woyke J. (2006) Eggs from Apis mellifera caucasica laying workers are larger than from queens, J. Apicult. Res. 45, 173-179.

Gillooly J.F., Dodson S.I. (2000) The relationship of egg size and incubation temperature to embryonic development time in univoltine and multivoltine aquatic insects, Freshw. Biol. 44, 595-604.

Gillooly J.F., Charnov E.L., West G.B., Savage V.M., Brown J.H. (2002) Effect of size and temperature on developmental time, Nature (Lond.) 417, 7073.

Gontarski H. (1938) Beobachtungen an eierlegenden Arbeiterinnen, Deutscher Imkerführer 12, 107113.

Harbo J.R., Bolten A.B. (1981) Development times of male and female eggs of the honey bee, Ann. Entomol. Soc. Am. 74, 504-506.

Hemmling C. (1991) Production and sexual maturity of drones in queenless colonies, Apidologie 22, 435-436.

Kapil R.P. (1962) Anatomy and histology of the female reproductive system of Apis indica $\mathrm{F}$. (Hymenoptera. Apidae), Insectes Soc. 9, 145-163.

Katzav-Gozansky T., Soroker V., Hefetz A. (2002) Honeybees Dufour's gland - idiosyncrasy of a new queen signal, Apidologie 33, 525-537.

Katzav-Gozansky T., Soroker V., Hefetz A., Cojocaru M., Erdmann D.H., Francke W. (1997) Plasticity of caste-specific Dufour 's gland secretion in the honey bee (Apis mellifera L.), Naturwissenschaften 84, 238-241.

Katzav-Gozansky T., Soroker V., Ibarra F., Francke W., Hefetz A. (2001) Dufour's gland secretion of the queen honeybee (Apis mellifera): an egg discriminator pheromone or a queen signal? Behav. Ecol. Sociobiol. 51, 76-86.

Katzav-Gozansky T., Soroker V., Kamer J., Schulz C.M., Francke W., Hefetz A. (2003) Ultrastrucutral and chemical characterization of egg surface of honeybee worker and queen-laid eggs, Chemoecology 13, 129-134.

Leoni G.G., Succu S., Berlinguer F., Rosati I., Bebbere D., Bogliolo L., Ledda S., Naitana S. (2006) Delay on the in vitro kinetic development of prepubertal ovine embryos, Anim. Reprod. Sci. 92, 373-383.

Lindauer M. (1954) Temperaturregulierung und Wasserhaushalt im Bienenstaat, Z. Vergl. Physiol. 36, 391-432.

Lorenz M.W. (2003) Adipokinetic hormone inhibits the formation of energy stores and egg production in the cricket Gryllus bimaculatus, Comp. Biochem. Physiol. B 136, 197-206.

Lorenz M.W. (2007) Oogenesis-flight syndrome in crickets: age-dependent egg production, flight performance, and biochemical composition of the flight muscles in adult female Gryllus bimaculatus, J. Insect Physiol. 53, 819-832.

Mackasmiel L.A.M., Fell R.D. (2000) Respiration rates in eggs of the honey bee, Apis mellifera, J. Apicult. Res. 39, 125-135.

Martin S.J., Châline N., Oldroyd B.P., Jones G.R., Ratnieks F.L.W. (2004) Egg marking pheromones of anarchistic worker honeybees, Behav. Ecol. 15, 839-844.

Martin S.J., Châline N., Ratnieks F.L.W., Jones G.R. (2005) Searching for the egg-marking signal in honeybees, J. Negative Results 2, 1-9.

Martin S.J., Jones G.R., Châline N., Middleton H., Ratnieks F.L.W. (2002) Reassessing the role of the 
honeybee (Apis mellifera) Dufour's gland in egg marking, Naturwissenschaften 89, 528-532.

Nonacs P. (2006) Nepotism and brood reliability in the suppression of worker reproduction in the eusocial Hymenoptera, Biol. Lett. 2, 577-579.

Page R.E., Erickson E.H. (1988) Reproduction by worker honey bees (Apis mellifera L.), Behav. Ecol. Sociobiol. 23, 117-126.

Pirk C.W.W., Neumann P., Hepburn R., Moritz R.F.A., Tautz J. (2004) Egg viability and worker policing in honey bees, Proc. Natl Acad. Sci. (USA) 101, 8649-8651.

Pirk C.W.W., Neumann P., Ratnieks F.L.W. (2003) Cape honeybees, Apis mellifera capensis, police worker-laid eggs despite the absence of relatedness benefits, Behav. Ecol. 14, 347-352.

Ratnieks F.L.W. (1992) Evidence for an egg-marking pheromone in the honey bee, Am. Bee J. 132, 813.

Ratnieks F.L.W. (1995) Evidence for a queenproduced egg-marking pheromone and its use in worker policing in the honey-bee, J. Apicult. Res. 34, 31-37.

Ratnieks F.L.W., Visscher P.K. (1989) Worker policing in the honeybee, Nature (Lond.) 342, 796-797.

Reginato R.D., Cruz-Landim C. (2003) Ovarian growth during larval development of queen and worker of Apis mellifera (Hymenoptera: Apidae): A morphometric and histological study, Braz. J. Biol. 63, 121-127.

Reinhardt E. (1960) Kernverhältnisse, Eisystem und Entwicklungsweise von Drohnen- und Arbeiterinneneiern der Honigbiene (Apis mellifera), Zool. Jahrbuch (Anatomie) 78, 167-231.

Rhein W. v. (1933) Über die Entstehung des weiblichen Dimorphismus im Bienenstaate, Roux's Arch. Dev. Biol. 129, 601-665.

Ribbands C.R. (1953) The behaviour and social life of honeybees, Bee Research Association, London.

Rizos D., Bermejo-Alvarez P., Gutierrez-Adan A., Lonergan P. (2008) Effect of duration of oocyte maturation on the kinetics of cleavage, embryo yield and sex ratio in cattle, Reprod. Fert. Develop. 20, 734-740.

Schäfer M.O., Dietemann V., Pirk C.W.W., Neumann P., Crewe R.M., Hepburn H.R., Tautz J., Crailsheim K. (2006) Individual versus social pathway to honeybee worker reproduction (Apis mellifera): pollen or jelly as protein source for oogenesis? J. Comp. Physiol. A-Sens. Neural Behav. Physiol. 192, 761-768.
Schuetz A. (1975) Cytoplasmic activation of starfish oocytes by sperm and divalent ionophore A23187, J. Cell Biol. 66, 86-94.

Snodgrass R.E. (1956) Anatomy of the honey bee, Comstock Publishers Associates, Ithaca, New York.

Taber S. (1961) Forceps design for transferring honey bee eggs, J. Econ. Entomol. 54, 247-250.

Tanaka E., Hartfelder K. (2004) The initial stages of oogenesis and their relation to differetial fertility in the honey bee (Apis mellifera) castes, Arthropod Struct. Dev. 33, 431-442.

Trougakos I.P., Margaritis L.H. (2002) Novel morphological and physiological aspects of insect eggs, in: Hilkers M., Meiners T. (Eds.), Chemoecology of insect eggs and egg deposition, Blackwell, Oxford, pp. 3-36.

Velthuis H.H.W., Alves D.D.A., Imperatriz-Fonseca V., Duchateau M.J. (2002) Worker bees and the fate of their eggs, Proc. Sect. Exp. Appl. Entomol. Neth. Entomol. Soc. 13, 97-102.

Visscher P.K. (1989) A quantitative study of worker reproduction in honey bee colonies, Behav. Ecol. Sociobiol. 25, 247-254.

Visscher P.K. (1996) Reproductive conflict in honey bees: A stalemate of worker egg-laying and policing, Behav. Ecol. Sociobiol. 39, 237-244.

Wegener J., Bienefeld K. (2009) Methoden zur Zucht der Honigbiene unter Nutzung der Nachkommen von Arbeiterinnen, Züchtungskunde 81, 265-278.

Wegener J., Lorenz M.W., Bienefeld K. (2009) Physiological consequences of prolonged nursing in the honey bee, Insect. Soc. 56, 85-93.

Winston M.L. (1987) The biology of the honey bee, Harvard University Press, Cambridge and London.

Wohlgemuth R. (1957) Die Temperaturregulation des Bienenvolkes unter regeltheoretischen Gesichtspunkten, Z. Vergl. Physiol. 40, 119-161.

Woyciechowski M., Lomnicki A. (1987) Multiple mating of queens and the sterility of workers among eusocial Hymenoptera, J. Theor. Biol. 128, 317327.

Woyke J. (1994) Comparison of the size of eggs from Apis mellifera L. queens and laying workers, Apidologie 25, 179-187.

Zander E. (1916) Die Ausbildung des Geschlechtes bei der Honigbiene (Apis mellifica L.), Z. Angew. Entomol. 3, 1-74.

Zander E. (1951) Der Bau der Biene, Eugen Ulmer, Stuttgart. 